\title{
Assessment of Landfill-emitted Gaseous Pollutants and Particulate Matters in Alimosho Local Government of Lagos state, Nigeria
}

\author{
Olutola Bob Soile \\ Moses O. Akiibinu \\ Temitope E. Bakare \\ Department of Biochemistry and Chemistry, \\ Caleb University Lagos, Nigeria
}

Gabriel O. Olaoye

Department of Architecture, Caleb University Lagos, Nigeria

Felix A Oyeyiola

Department of Biochemistry and Chemistry,

Caleb University Lagos, Nigeria

Jacob A. Adeola

Department of Architecture, Caleb University Lagos, Nigeria

Bolaji B. Alarape

Department of Biochemistry and Chemistry,

Caleb University Lagos, Nigeria

\section{Olaniyi O. Duduyemi}

Department of Chemical Pathology and Immunology,

Olabisi Onabanjo University, Ago-Iwoye, Ogun State

John I. Anetor

Department of Chemical Pathology, University of Ibadan, Nigeria

Doi: 10.19044/esj.2018.v14n24p272 URL:http://dx.doi.org/10.19044/esj.2018.v14n24p272

\begin{abstract}
Information on landfill-emitted pollutants in Nigeria cities has consequently become a priority. This study was designed to assess the air quality of landfill sites and the nearby communities in the Alimosho Local Government Area of Lagos state, Nigeria. Five public landfills in use since about thirty years ago were chosen for this study. A lightly populated area, free from other sources of air pollution served as control. Target points for the study were the centre of landfill (CLF), 50M from CLF, 100M from CLF, and a radius of $100 \mathrm{M}$ away from landfill. Levels of selected gaseous pollutants $\left(\mathrm{NO}_{2}, \mathrm{O}_{3}, \mathrm{H}_{2} \mathrm{~S}\right.$ and $\left.\mathrm{CO}\right)$ and particulate matters (PM2.5 and PM10) were determined in the landfill environments and control (unpolluted area), using
\end{abstract}


Aeroqual Series 500 with sensors for $\mathrm{NO}_{2}, \mathrm{O}_{3}, \mathrm{H}_{2} \mathrm{~S}$, CO, PM2.5 and PM10. The result showed that levels of $\mathrm{H}_{2} \mathrm{~S}$ were significantly $(\mathrm{p}<0.001)$ higher at the CLF, 50M from CLF and 100M from CLF compared with unpolluted area. There was no significant ( $p>0.05$ ) difference when the level of $\mathrm{H}_{2} \mathrm{~S}$ in $100 \mathrm{M}$ radius was compared with the unpolluted area. Levels of $\mathrm{CO}$ were significantly $(\mathrm{p}<0.001)$ higher at the CLF, 50M from CLF, 100M from CLF and $100 \mathrm{M}$ radius compared with unpolluted area. The levels of $\mathrm{O}_{3}$ were significantly ( $\mathrm{p}<0.001$ ) higher at the CLF, 50M from CLF, 100M from CLF and $100 \mathrm{M}$ radius compared with unpolluted area. Levels of VOC were significantly ( $\mathrm{p}<0.001$ ) higher at the CLF, 50M from CLF, 100M from CLF and $100 \mathrm{M}$ radius compared with unpolluted area. The levels of $\mathrm{NO}_{2}$ were significantly ( $\mathrm{p}<0.001$ ) higher at the CLF, 50M from CLF, 100M from CLF and $100 \mathrm{M}$ radius compared with the unpolluted area. The levels of PM2.5 increased significantly $(\mathrm{p}<0.001)$ at the CLF, 50M from CLF, 100M from CLF and $100 \mathrm{M}$ radius compared with the unpolluted area. The levels of PM10 were also significantly ( $\mathrm{p}<0.001$ ) higher at the CLF, 50M from CLF, 100M from CLF and $100 \mathrm{M}$ radius compared with the unpolluted area. In conclusion, communities close to landfills may be polluted with toxic gases and particulate matters. Further investigation is needed to validate the safe distance of residential areas from landfills to avert the risks of toxicity associated with gaseous pollutants.

Keywords: Landfill, emitted pollutants, dispersion, environment.

\section{Introduction}

Landfilling is the most common waste management practice in Nigeria and many other developing countries. The landfills are unwillingly converted to markets, restaurants, shopping malls and motor parks. Available reports show that biodegradation of the landfill particles contribute to the biogenic emissions of pollutants into the environment through combustion and physicochemical changes (Ajao, 2002). Nag et al (2016) reported that landfills emit high levels of greenhouse gases such as nitrogen oxide during the biodegradation of solid waste or combustion of nitrogen-containing solid waste during the microbial process of nitrification and de-nitrification. Gases including non-methanic volatile organic compounds, polychlorinated dibenzo-p-dioxins, dibenzofurans, dioxin-like polychlorobiphenyls, polycyclic aromatic hydrocarbons, benzene and vinyl chloride monomer and odor emitted by the landfills are produced through microbial anaerobic digestion (Palmiotto et al, 2014; Powell et al, 2015). However, the biogenic hydrocarbons are actively involved in the chemistry of the atmosphere. Once certain chemicals enter the stratosphere, reactions catalyzed by ultraviolet radiation convert them into highly reactive species including sulfur dioxide 
$\left(\mathrm{SO}_{2}\right)$, hydrogen sulphide $\left(\mathrm{H}_{2} \mathrm{~S}\right)$, carbon monoxide $\left(\mathrm{CO}_{2}\right)$, ozone $\left(\mathrm{O}_{3}\right)$ and oxides of nitrogen that can have a devastating effect on stratospheric ozone (Kumar, 2008). For example, $\mathrm{O}_{3}$ production is enhanced when sunlight strikes a mixture of hydrocarbons to yield varieties of hydrocarbons and their oxidation products. The oxidation products including $\mathrm{NO}_{2}$ and $\mathrm{O}_{3}$ are built in the mixture (Blacet, 1952). Each time this cycle of reactions occurs, a molecule of $\mathrm{NO}$ is oxidized to $\mathrm{NO}_{2}$; and $\mathrm{O}_{3}$ is increased through the subsequent photolysis of $\mathrm{NO}_{2}$. Anderson (2010) also reported that photochemical $\mathrm{O}_{3}$ and smog are created by nitrogen oxides and hydrocarbons as they react in sunlight. Reactions of nitrous oxides and volatile organic compounds in the atmosphere aided by sunlight, combustion of fossil fuels and emissions from motor vehicles and stationary sources can lead to the production of $\mathrm{O}_{3}$ and other gaseous pollutants. The nature of $\mathrm{O}_{3}$ allows it to be transported by wind hence $\mathrm{O}_{3}$ can be found hundreds kilometers from their origins. These emitted gases and particles have potentials to pollute the immediate natural environment, and spread to nearby communities. The consequent adverse environmental changes could be more in highly populated communities without proper waste management. Varied concentrations of gaseous pollutants $\left(\mathrm{SO}_{2}, \mathrm{NO}_{2}\right.$ and $\left.\mathrm{NH}_{3}\right)$ at weekdays and weekends have been reported along a populated urban region of Kolkata (Karar et al., 2016). Palaniswamy et al. (1995) reported that the gaseous pollutants could affect development and growth of crop plants. Multiple exposures to such high levels of gases have been associated with upper respiratory track irritation, disruption of oxygen transport, and finally central nervous system disorders (Jumpponen et al, 2013). Numata et al. (2008) also reported lower body weight in landfill birds, In a study conducted by Richard et al. (2009), several organic pollutants were reported in pregnant females.

Particulate matters (PM) originate from many anthropogenic and natural sources that form secondary inorganic and organic particles with variable physical, chemical, and morphological characteristics. Previous study by Kroll et al. (2013) reveals that the components of PM include chloride, nitrate, ammonium, sulfate, 68 chemical elements and endotoxins. These PM may elicit various effects and thus, may affect the degree of pro-inflammatory response and oxidative potential due to exposure. The mean concentrations of metals in the PM10 in Dhanbad region at Jharkand, India were found in the order of $\mathrm{Fe}>\mathrm{Cu}>\mathrm{Zn}>\mathrm{Mn}>\mathrm{Cr}>\mathrm{Cd}>\mathrm{Pb}>\mathrm{Ni}$ (Dubey et al, 2012). The consequences of exposure to these particulate matters range from infant mortality to respiratory, cardiovascular and mental disorders. Previous studies confirmed that an increase in PM2.5 results in an increased risk of hospitalization for myocardial infarction, heart failure, cardiac arrest and inflammatory responses (Higgins et al. 2010; Huttunen et al. 2012). With regard to non-fatal outcomes, the risk of myocardial infarction has been 
estimated to be 1.48 times greater for a small increase in particulate air pollution $(25 \mu \mathrm{g} / \mathrm{m} 3$ in the preceding two hours). This study was designed to determine the air quality of the landfill and a radius of $100 \mathrm{M}$ distance from the landfills to predict the predisposition of the communities to pollutants.

\section{Materials and Methods:}

\section{Materials:}

Five landfills in Alimosho Local Government Area of Lagos state, Nigeria were chosen for this study. The local government is a densely populated area where commercial and government waste collectors use the landfills regularly. The landsfills, each occupying an area of about two kilometer square contained organic, inorganic, condemned electronics etc; and had being in use since almost thirty years ago. Wind from Atlantic Ocean drives the potential pollutants toward the residential areas. A serene lightly populated area with less commercial activities, about fifteen kilometers away from the landfill areas served as a control for this study. This control community did not have landfill or manufacturing industry that could cause pollution. Target points for the study were the centre of landfill (CLF), 50M from CLF, 100M from CLF and a radius of 100M away from landfill.

\section{Methods:}

Levels of gaseous pollutants and particulate matters were measured in all the landfill areas and unpolluted area (control) by using Aeroqual Series 500 with sensors for $\mathrm{NO}_{2}, \mathrm{O}_{3}, \mathrm{H}_{2} \mathrm{~S}, \mathrm{CO}, \mathrm{PM} 2.5$ and PM10 as recommended by the manufacturer.

\section{Statistical analysis:}

All statistical analyses were performed using the Statistical Package for the Social Sciences (SPSS) for windows, version 21. The data were expressed as Mean \pm SD. Student $(\mathrm{t})$ test was used for the comparison of gaseous pollutants and particulate matters in landfills and control. The changes were considered significant, when p-values were less than 0.05 .

\section{Results:}

As demonstrated in Table 1 , there were significant $(\mathrm{p}<0.05)$ differences observed in the distributions of landfill-emitted pollutants. The levels of pollutants varied with the distance from the center of the landfills (Table 2). $\mathrm{H}_{2} \mathrm{~S}$ were significantly $(\mathrm{p}<0.001)$ higher at the CLF, 50M from CLF and $100 \mathrm{M}$ from CLF compared with unpolluted area. There was no significant ( $p>0.05$ ) difference when the level of $\mathrm{H}_{2} \mathrm{~S}$ in unpolluted area was compared with $100 \mathrm{M}$ away from the landfill. Levels of CO were significantly $(\mathrm{p}<0.001)$ higher at the CLF, 50M from CLF, 100M from CLF and 100M away from the 
landfill compared with unpolluted area. The levels of $\mathrm{O}_{3}$ were significantly ( $\mathrm{p}<0.001$ ) higher at the CLF, 50M from CLF, 100M from CLF and 100M away from the landfill compared with unpolluted area. Levels of VOC were significantly ( $\mathrm{p}<0.001$ ) higher at the CLF, 50M from CLF, 100M from CLF and $100 \mathrm{M}$ away from the landfill compared with unpolluted area. $\mathrm{NO}_{2}$ levels were significantly $(\mathrm{p}<0.001)$ higher at the CLF, 50M from CLF, 100M from CLF and 100M away from the landfill compared with unpolluted area. Table 3 shows that levels of PM2.5 increased significantly $(\mathrm{p}<0.001)$ at the CLF, 50M from CLF, 100M from CLF and 100M away from the landfill compared with unpolluted area. Levels of PM10 were also significantly $(p<0.001)$ higher at the CLF, 50M from CLF, 100M from CLF and 100M away from the landfill compared with unpolluted area.

Table 1: Levels of Gaseous Pollutants and Particulate Matter in Land Fill Areas and Controls

\begin{tabular}{|c|c|c|c|c|c|c|c|}
\hline Pollutants & $\begin{array}{c}\text { Center of } \\
\text { landfill (CLF) }\end{array}$ & $\begin{array}{l}\text { 50M from } \\
\text { CLF }\end{array}$ & $\begin{array}{l}\text { 100M from } \\
\text { CLF }\end{array}$ & $\begin{array}{l}\text { 100M away } \\
\text { from landfill }\end{array}$ & $\begin{array}{c}\text { Unpolluted area } \\
\text { (control) }\end{array}$ & F-Test & p-values \\
\hline $\begin{array}{l}\text { PM 2.5 } \\
(\mu \mathrm{g} / \mathrm{m} 3)\end{array}$ & $57.9 \pm 11.4$ & $47.6 \pm 12.6$ & $35.2 \pm 7.3$ & $30.5 \pm 7.0$ & $13.1 \pm 1.0$ & 15.9 & $<0.001 *$ \\
\hline $\begin{array}{l}\text { PM 10 } \\
(\mu \mathrm{g} / \mathrm{m} 3)\end{array}$ & $122.0 \pm 16.4$ & $92.8 \pm 15.2$ & $74.0 \pm 8.1$ & $56.2 \pm 12.9$ & $34.6 \pm 4.0$ & 33.1 & $<0.001 *$ \\
\hline $\mathrm{H}_{2} \mathrm{~S}(\mathrm{ppb})$ & $8.1 \pm 1.1$ & $6.5 \pm 1.0$ & $5.4 \pm 0.5$ & $4.7 \pm 0.7$ & $3.7 \pm 0.5$ & 20.9 & $<0.001 *$ \\
\hline $\begin{array}{l}\mathrm{CO} \\
(\mathrm{ppb})\end{array}$ & $1029.6 \pm 30.9$ & $990.8 \pm 60.4$ & $942.8 \pm 6.25$ & $880.0 \pm 76.5$ & $287.5 \pm 34.0$ & 122.7 & $<0.001 *$ \\
\hline $\mathrm{O}_{3}(\mathrm{ppb})$ & $136.6 \pm 10.0$ & $112.4 \pm 18.2$ & $93.0 \pm 14.0$ & $77.8 \pm 12.5$ & $44.8 \pm 4.3$ & 32.4 & $<0.001 *$ \\
\hline VOC (ppb) & $220.0 \pm 53.9$ & $168.0 \pm 23.9$ & $148.0 \pm 25.4$ & $122.6 \pm 25.6$ & $47.8 \pm 2.1$ & 17.7 & $<0.001 *$ \\
\hline $\mathrm{NO}_{2}(\mathrm{ppb})$ & $150.0 \pm 22.4$ & $111.2 \pm 30.5$ & $93.6 \pm 31.4$ & $81.0 \pm 28.3$ & $8.6 \pm 1.4$ & 17.4 & $<0.001^{*}$ \\
\hline
\end{tabular}

Table 2: Distribution of Gaseous Pollutants in Landfill Areas and Controls

\begin{tabular}{|c|c|c|c|c|c|}
\hline Gaseous pollutants & $\mathrm{H}_{2} \mathrm{~S}(\mathrm{ppb})$ & $\mathrm{CO}(\mathrm{ppb})$ & $\mathrm{O}_{3}(\mathrm{ppb})$ & VOC (ppb) & $\mathrm{NO}_{2}(\mathrm{ppb})$ \\
\hline $\begin{array}{l}\text { Unpolluted area } \\
\text { (control) }\end{array}$ & $3.7 \pm 0.5$ & $287.5 \pm 34.0$ & $44.8 \pm 4.3$ & $47.8 \pm 2.1$ & $8.6 \pm 1.4$ \\
\hline $\begin{array}{l}\text { Center of land fill } \\
(\mathrm{CLF})\end{array}$ & $8.1 \pm 1.1$ & $1029.6 \pm 30.9$ & $136.6 \pm 10.0$ & $220.0 \pm 53.9$ & $150.0 \pm 22.4$ \\
\hline $50 \mathrm{M}$ from CLF & $6.5 \pm 1.0$ & $990.8 \pm 60.4$ & $112.4 \pm 18.2$ & $168.0 \pm 23.9$ & $111.2 \pm 30.5$ \\
\hline 100M from CLF & $5.4 \pm 0.5$ & $942.8 \pm 6.25$ & $93.0 \pm 14.0$ & $148.0 \pm 25.4$ & $93.6 \pm 31.4$ \\
\hline $\begin{array}{l}100 \mathrm{M} \text { away from } \\
\text { landfill }\end{array}$ & $4.7 \pm 0.7$ & $880.0 \pm 76.5$ & $77.8 \pm 12.5$ & $122.6 \pm 25.6$ & $81.0 \pm 28.3$ \\
\hline $\mathrm{Pa}$ & $<0.001 *$ & $<0.001 *$ & $<0.001 *$ & $<0.001 *$ & $<0.001 *$ \\
\hline $\mathrm{Pb}$ & $<0.001 *$ & $<0.001 *$ & $<0.001 *$ & $<0.001 *$ & $<0.001 *$ \\
\hline $\mathrm{Pc}$ & $<0.001 *$ & $<0.001 *$ & $<0.001 *$ & $<0.001 *$ & $<0.001 *$ \\
\hline $\mathrm{Pd}$ & $>0.05$ & $<0.001 *$ & $<0.001 *$ & $<0.001 *$ & $<0.001 *$ \\
\hline $\begin{array}{l}\mathrm{Pa}=\text { level of diffe } \\
\mathrm{Pb}=\text { level of diffe } \\
\mathrm{Pc}=\text { level of diffe } \\
\mathrm{Pd}=\text { level of diffe } \\
*=\mathrm{P}<0.05 \text { (signi }\end{array}$ & $\begin{array}{l}\text { ence between } \\
\text { ence between } \\
\text { ence between } \\
\text { ence between } \\
\text { icantly differe }\end{array}$ & $\begin{array}{l}\text { ues at CLF an } \\
\text { ues at } 50 \mathrm{M} \text { fro } \\
\text { ues at } 100 \mathrm{M} \mathrm{f} \\
\text { ues at } 100 \mathrm{M} \text { a } \\
\text { rom controls) }\end{array}$ & $\begin{array}{l}\text { ntrol. } \\
\text { CLF and cont } \\
\text { from landfil }\end{array}$ & control. & \\
\hline
\end{tabular}


Table 3: Distribution of Particulate Matters in Land Fill Areas and Controls

\begin{tabular}{|lccccccccc|}
\hline $\begin{array}{l}\text { Particulate } \\
\text { matters } \\
(\mathrm{PM})\end{array}$ & $\begin{array}{c}\text { Unpolluted } \\
\text { area } \\
\text { control) }\end{array}$ & $\begin{array}{c}\text { Center of } \\
\text { landfill } \\
\text { (CLF) }\end{array}$ & $\begin{array}{l}50 \mathrm{M} \text { from } \\
\text { CLF }\end{array}$ & $\begin{array}{l}100 \mathrm{M} \\
\text { from CLF }\end{array}$ & $\begin{array}{l}100 \mathrm{M} \\
\text { from } \\
\text { landfill }\end{array}$ & pa & $\mathrm{pb}$ & $\mathrm{pc}$ & $\mathrm{pd}$ \\
\hline $\begin{array}{l}\mathrm{PM} 2.5 \\
(\mu \mathrm{g} / \mathrm{m} 3)\end{array}$ & $13.1 \pm 1.0$ & $57.9 \pm 11.4$ & $47.6 \pm 12.6$ & $35.2 \pm 7.3$ & $30.5 \pm 7.0$ & $<0.001^{*}$ & $<0.001^{*}$ & $<0.001^{*}$ & $<0.001^{*}$ \\
$\begin{array}{l}\mathrm{PM} 10 \\
(\mu \mathrm{g} / \mathrm{m} 3)\end{array}$ & $34.6 \pm 4.0$ & $122.0 \pm 16.4$ & $92.8 \pm 15.2$ & $74.0 \pm 8.1$ & $56.2 \pm 12.9$ & $<0.001^{*}$ & $<0.001^{*}$ & $<0.001^{*}$ & $<0.001^{*}$ \\
\hline
\end{tabular}

$\mathrm{Pa}=$ level of difference between values at CLF and control.

$\mathrm{Pb}=$ level of difference between values at 50M from CLF and control.

$\mathrm{Pc}=$ level of difference between values at 100M from CLF and control.

$\mathrm{Pd}=$ level of difference between values at $100 \mathrm{M}$ away from landfill and control.

$* \mathrm{P}<0.05=$ significantly different from control.

\section{Discussion:}

Owing to increasing industrialization and increasing urbanization in many developing countries, proper waste management remains a major concern currently. The health implications of this growing problem is poorly recognized and investigated. This study consequently addresses this environmental challenge in one of the densely populated cities in Nigeria. The elevated levels of gaseous pollutants and particulate matters observed in this study confirmed the hypothesis that landfills emit pollutants into the nearby communities. Higher levels of $\mathrm{NO}_{2}$ and $\mathrm{CO}$ were earlier reported in a densely populated area of Port Harcourt, Nigeria. Our findings therefore corroborate that of Paraskaki et al (2005) where concentrations of several landfill-emitted pollutants were significantly higher than the World Health Organization reference lifetime exposure health criteria. Significantly higher levels of $\mathrm{H}_{2} \mathrm{~S}$, $\mathrm{CO}, \mathrm{O}_{3}$, VOC and $\mathrm{NO}_{2}$ observed in this study could be due to decomposition of organic matters, oxidation and several other reactions favored by the environmental conditions of the landfill sites. Occasional burning of waste containing electric utilities in the dumping sites at very high temperatures could also contribute to significantly higher levels of $\mathrm{NO}_{2}$ in the landfills. Also, the $\mathrm{NO}_{2}$ could be a product of landfill-emitted $\mathrm{N}_{2} \mathrm{O}$ (Jia et al, 2014).

Except $\mathrm{H}_{2} \mathrm{~S}$, all other gaseous pollutants $\left(\mathrm{NO}_{2}, \mathrm{VOC}, \mathrm{CO}\right.$ and $\left.\mathrm{O}_{3}\right)$ showed significantly higher levels in nearby communities $100 \mathrm{M}$ away from the landfills. This could be due to high levels of emission and ability of the wind to transport the gases. Previous studies show that levels of pollutants beyond the WHO permissive limits have pathological effects. Halliwell et al (1999) stressed that excess intake of $\mathrm{NO}_{2}$ could enhance in-vivo production of peroxynitrite, oxidative stress, other metabolic diseases and cancers (Choudhari et al, 2013). The higher level of $\mathrm{NO}_{2}$ emitted by landfills could also cause acid rains, skin diseases and damaged roofing sheets (Reddy et al., 2004). Elevated levels of CO in the landfills and communities $100 \mathrm{M}$ away from the landfills could pose dangers to the inhabitants of the landfill 
communities. Many of the common side effects of $\mathrm{CO}$ intoxication include its affinity (about 200 times that of oxygen) for haemoglobin, that enhances its ability to easily displace oxygen in the system. A similar study by Sroczyński et al. (1993) showed higher level of carboxyhaemoglobin in the workers of the furnace room and of the carbon derivatives department.

Several studies suggest that landfills emit particulate matters beyond the prescribed standards (Gurdeep and Puri, 2004). Praveena et al (2015) have reported high levels of heavy metals $(\mathrm{Pb}, \mathrm{Cd}$, and $\mathrm{Cu})$ in the particulate matters deposited on windows, floor and fan at a primary school in Sri Serdang, Malaysia. Significantly higher concentrations of particulate matters observed in this study decreased with increase in the distance from the center of landfill. This study is the first to monitor the distribution pattern of landfill-emitted PM2.5 and PM10 in Nigeria. The significantly higher levels of PM2.5 and PM10 observed in these communities 100M away from the landfills could be a novelty of this study. This corroborates the previous reports of Sastry et al. (2015) that, dispersion of pollutants is wind dependent and can diffuse to distant communities. He et al. (2016) reported that PM2.5 has higher concentrations of $\mathrm{Pb}, \mathrm{Cu}, \mathrm{As}$ and polycyclic aromatic hydrocarbons, while PM10 contains higher amounts of microbial elements lipopolysaccharide, $\beta$ glucan, $\mathrm{Si}, \mathrm{Al}, \mathrm{Fe}$, and Ti. This study may therefore suggest that landfills can emit dangerous particulate matters that can be dispersed to the neighboring communities. The present report and some previous ones could buttress the findings of $\mathrm{Xu}$ et al. (2017) and Wang et al. (2017) that short-term exposure to high levels of PM2.5 and PM10 caused the hospitalization of some people with inflammatory heart diseases and immediate decrease in lung function owing to the virtue of the loss of pulmonary epithelium integrity. Traversi et al (2015) also reported that a number of compounds found in particulate matters of an aerodynamic diameter $<2.5$ (PM2.5) can interact with DNA either directly or after enzymatic transformation to induce DNA modifications. Neisi et al (2017) also reported that higher values of inflammatory biomarker and impaired lung function were observed in individuals exposed to dust. Sato et al (2016) and Benmerad et al, (2017) stressed that a short-term exposure to high levels of particulate matters may have adverse effects on cough reflex and urge-to-cough thresholds, pulmonary function, cough-related quality of life and lower forced expiratory volume and forced vital capacity in lung transplant recipients.

\section{Conclusion:}

It could be concluded that population living in communities close to the landfills are likely to be polluted with gaseous pollutants and particulate matters. There is a high probability that the study conducted by Paraskaki et al (2005) in the Ano Liosia landfill site in the greater Athens, where the 
minimum downwind distance of the health-risk zone was calculated to be equal to $1.5 \mathrm{~km}$ from the landfill could differ from Nigerian environment. Since Nigeria has different weather and climatic conditions, the distance of the health-risk zone from the landfill may be different. Since pollution is a growing problem in many industrializing countries including Nigeria, further investigations may be needed to validate the safe distance of residential areas from landfills.

Acknowledgement: We appreciate Mr. Bella Orsman, Ministry of Environment, Alausa, Ikeja, Lagos Nigeria for the technical support.

Competing Interests: The authors declared that they have no competing interests.

\section{Authors Contributions:}

MOA, BBA, OOD, GOO, JAA, OBS, FAO and JIA designed the study, MOA, TEB and BBA did the analysis, and all authors prepared and approved the final manuscript.

\section{References:}

1. Ajao E. A and Anurigwo S (2002). Land-Based Sources of Pollution in the Niger Delta, Nigeria. Ambio. 31: 5, 442-445

2. Andersen, P. C., Williford, C. J., and Birks, J. W (2010). Miniature Personal Ozone Monitor Based on UV Absorbance, Anal. Chem. 82, 7924-7928, doi:10.1021/ac1013578,

3. Benmerad M, Slama R, Botturi K, Claustre J. et al,( 2017). Chronic Effects of Air Pollution on Lung Function After Lung Transplantation in the Systems Prediction of Chronic Lung Allograft Dysfunction (SysCLAD) Study. Eur Respir J. 49 (1). pii: 1600206. doi: 10.1183/13993003.00206-2016

4. Blacet, F. E (1952). Photochemistry in the lower atmosphere, Ind. Eng. Chem. 44, 1339

Choudhari SK, Chaudhary M, Bagde S, Gadbail AR, and Joshi V (2013): Nitric oxide and cancer: a review. World J Surg Oncol. 11: 118.

5. Dubey, B., Pal, A.K., Singh, G (2012). Trace metal composition of airborne particulate matter in the coal mining and non-mining areas of Dhanbad Region, Jharkhand, India atmospheric pollution research. 3, 238-246.

6. Gurdeep S, Puri SK (2004). Air quality assessment in Korba coalfield. Indian J Air Polln Contl. 4 (2), 31-41. 
7. Halliwell Bl, Zhao K, Whiteman M (1999). Nitric oxide and peroxynitrite. The ugly, the uglier and the not so good personal view of recent controversies,Free Radic Res. 6:651-669.

8. He M, Ichinose T,Yoshida,Shiba F Arashidani K Takano H,Sun G,Shibamoto T. (2016). Difference in allergic inflammatory responses in murine Lungs:comparison of PM2.5 and coarse PM collected during th hazy events in Chinese city.Toxicol. 28. 706-718.

9. Higgins ITI, Arcy JB, Gibbons Dl, Avol EL, Gross KB. (2010). Immunotoxicological properties of airborne particles at landfill, urban and rural sites and their relation to microbial concentrations.J Environ Monit. 12(6):1368-74. doi: 10.1039/c002579h.

10. Huttunen K, Siponen T et al. (2012). Low-level exposure to ambient particulate matter is associated with systemic inflammation in ischemic heart disease patients. Environ Res. 116:44-51

11. Jia MS Wang XJ, Chen SH.( 2014). Nitrous oxide emissions from municipal solid waste landfills and its measuring methodology. Ying Yong Sheng Tai Xue Bao. 2014 Jun;25(6):1815-24.

12. Jumpponen M1, Rönkkömäki H, Pasanen P, Laitinen J. (2013). Occupational exposure to gases, polycyclic aromatic hydrocarbons and volatile organic compounds in biomass-fired power plants. Chemosphere. 90(3):1289-93. doi: 10.1016/j.chemosphere.2012.10.001..

13. Karar K., Gupta A. K., Kumar A., Biswas A. K. (2016). Seasonal Variations of PM10 and TSP in Residential and Industrial Sites in an Urban Area of Kolkata, India. Environmental Monitoring and Assessment. 118(1-3):369-81.

14. Kroll A, Gietl J. K, Wiesmüller G. A, Günsel A, Wohlleben W, Schnekenburger J, Klemm O. (2013). In vitro toxicology of ambient particulate matter: Correlation of cellular effects with particle size and components. Environmental Toxicology. 28, (2): 76-86.

15. Kumar, S. S., Singh, N. A.,Kumar, V., Sunisha, B., Preeti, S., Deepali, S. and Nath, S. R. (2008). Impact of dust emission on plant vegetation in the vicinity of cement plant." Environmental Engineering and Management Journal. 7(1): 31-35.

16. Li H, Nitivattananon V, Li P. (2015). Municipal solid waste management health risk assessment from air emissions for China by applying life cycle analysis. Waste Manag Res. 33(5):401-9. doi: 10.1177/0734242X15580191.

17. Liu J, Wu W, Chen C, Sun F, Chen Y. (2011). Prokaryotic diversity, composition structure, and phylogenetic analysis of microbial communities in leachate sediment ecosystems. Appl Microbiol Biotechnol. 91(6):1659-75. doi: 10.1007/s00253-011-3354-8. 
18. Nag M, ShimaokaT. and Komiya T. (2016). Nitrous oxide production during nitrification from organic solid waste under temperature and oxygen conditions. Environmental Technology. 37, 22.

21. Neisi A, Goudarzi G., Akbar Babaei A, Vosoughi M, Hashemzadeh H, Naimabadi A, Mohammadi M.J., Hashemzadeh B. (2016). Study of heavy metal levels in indoor dust and their health risk assessment in children of Ahvaz city, Iran. Toxin. Rev. 35 (1-2), 16-23.

22. Numata M, Fawcett JP, Saville DJ, Rosengren RJ. (2008). Hepatic cytochrome P450 activity and pollutant concentrations in paradise shelducks and southern black-backed gulls in the South Island of New Zealand. Ecotoxicology. 17(8):697-708.

23. Palaniswamy, M., Gunamani, T. and Swaminathan, K. (1995). Effect of air pollution caused by automobile exhaust gases on crop plants.Proc. Acd Environ. Biol. 4 (2): 255-260.

24. Palmiotto M, Fattore E, Paiano V, Celeste G, Colombo A, Davoli E. (2014). Influence of a municipal solid waste landfill in the surrounding environment: toxicological risk and odor nuisance effects. Environ Int. 68:16-24.

25. Paraskaki I, Lazaridis M. (2005). Quantification of landfill emissions to air: a case study of the Ano Liosia landfill site in the greater Athens area. Waste Manag Res. 23(3):199-208.

26. Powell, Jon T.; Townsend, Timothy G.; Zimmerman, Julie B.(2015). "Estimates of solid waste disposal rates and reduction targets for landfill gas emissions". Nature Climate Change. 6: 162-165.

27. Praveena SM, Abdul Mutalib NS \& Zaharin Aris A. (2015). Determination of Heavy Metals in Indoor Dust From Primary School (Sri Serdang, Malaysia): Estimation of the Health Risks. Environmental Forensics. 16, 3. 257-263.

28. Reddy MK, Rao KGR, Rao IR. (2004). Air quality status of Visakhapatnam (India)-indices basis. Environment Monitoring Assessment. 93: 1-12.

29. Richard Y. Wang, Ram B. Jain, Amy F. Wolkin, Carol H. Rubin, and Larry L. Needham. (2009). Serum Concentrations of Selected Persistent Organic Pollutants in a Sample of Pregnant Females and Changes in Their Concentrations during Gestation. Environ Health Perspect. 117:1244-1249.

30. Sastry V.R., Ram Chandrar K., Nagesha K. V., Muralidhar E., Shoeb Mohiuddin M. (2015). Pridiction and Analysis of Dust Dispersion from Drilling Operation in Open Cast Coal Mines. Procedia Eart and Planetry Science. 11: 303-311.

31. Sato R, Gui P, Ito K, Kohzuki M and Ebihara S. (2016). Effect of Short-Term Exposure to High Particulate Levels on Cough Reflex 
Sensitivity in Healthy Tourists: A Pilot Study. Open Respir Med J. 10: 96-104.

32. Srocynski JI,Kaminska-Galwas B. (1993). Effect of working in a coke plant on levels of carbon monoxide hemoglobin in employed workers. 442:117-20.

33. Traversi D1, Cervella P, Gilli G. (2015). Evaluating the genotoxicity of urban PM2.5 using PCR-based methods in human lung cells and the Salmonella TA98 reverse test. Environ Sci Pollut Res Int. (2):1279-89.

34. Wang XB, Jin HF, Tang CS, Du JB. (2011). "The biological effect of endogenous sulfur dioxide in the cardiovascular system.". Eur $J$ Pharmacol. 16;670(1):1-6. doi: 10.1016/j.ejphar.2011.08.031.

35. Xu, G.L., Bestor, T. H., Bourc'his D., Hsieh, C. L.,Tommerup, N., Bugge, M., Hulten, M., Qu, X., Russo, J.J.,and Viegas-Pequignot, E. (1999). Chromosome instability and immunodeficiency syndrome caused by mutations in a DNA methyltransferase gene. Nature. 402, 186-191. 